This item was submitted to Loughborough's Research Repository by the author.

Items in Figshare are protected by copyright, with all rights reserved, unless otherwise indicated.

\title{
Energy- and exergy-based working fluid selection and performance analysis of a high-temperature PEMFC-based micro combined cooling heating and power system
}

\section{PLEASE CITE THE PUBLISHED VERSION}

http://dx.doi.org/10.1016/j.apenergy.2017.07.031

\section{PUBLISHER}

(C) Elsevier

\section{VERSION}

AM (Accepted Manuscript)

\section{PUBLISHER STATEMENT}

This work is made available according to the conditions of the Creative Commons Attribution-NonCommercialNoDerivatives 4.0 International (CC BY-NC-ND 4.0) licence. Full details of this licence are available at: https://creativecommons.org/licenses/by-nc-nd/4.0/

\section{LICENCE}

CC BY-NC-ND 4.0

\section{REPOSITORY RECORD}

Chang, Huawei, Zhongmin Wan, Yao Zheng, Xi Chen, Shuiming Shu, Zhengkai Tu, Siew H. Chan, Rui Chen, and Xiaodong Wang. 2017. "Energy- and Exergy-based Working Fluid Selection and Performance Analysis of a High-temperature Pemfc-based Micro Combined Cooling Heating and Power System". figshare.

https://hdl.handle.net/2134/26112. 


\title{
Energy- and exergy-based working fluid selection and performance analysis of a high-temperature PEMFC-based micro combined cooling heating and power system
}

\author{
Accepted for publication by Applied Energy
}

Huawei Chang ${ }^{\mathrm{a}}$, Zhongmin Wana ${ }^{\mathrm{b}, *}$, Yao Zheng $^{\mathrm{a}}, \mathrm{Xi} \mathrm{Chen}^{\mathrm{b}}$, Shuiming Shu ${ }^{\mathrm{a}}$, Zhengkai $\mathrm{Tu}^{\mathrm{a}, \mathrm{c}, \mathrm{c},}$, Siew Hwa Chan $^{c}$, Rui Chen ${ }^{\mathrm{d}}$, Xiaodong Wang ${ }^{\mathrm{e}}$

${ }^{a}$ School of Energy and Power Engineering, Huazhong University of Science and Technology, Wuhan 430074, China

${ }^{\mathrm{b}}$ College of Information and Communication Engineering, Hunan Institution of Science and Technology, Yueyang 414006, China

c Energy Research Institute, Nanyang Technological University, 50 Nanyang Avenue, 637553, Singapore

${ }^{d}$ Department of Aeronautical and Automotive Engineering, Loughborough University, Leicestershire LE11 3TU, United Kingdom

e Research Center of Engineering Thermophysics, North China Electric Power University, Beijing 102206, China

\begin{abstract}
A combined cooling heating and power (CCHP) system based on high-temperature proton exchange membrane fuel cell (PEMFC) is proposed. This CCHP system consists of a PEMFC subsystem, an organic Rankine cycle (ORC) subsystem and a vapor compression cycle (VCC) subsystem. The electric power of the CCHP system is $8 \mathrm{~kW}$ under normal operating conditions, the domestic hot water power is approximately $18 \mathrm{~kW}$, and the cooling and heating capacities are $12.5 \mathrm{~kW}$ and $20 \mathrm{~kW}$, respectively. Energy and exergy performance of the CCHP system are thoroughly analyzed for six organic working fluids using Matlab coupled with REFPROP. R601 is chosen as the working fluid for ORC subsystem based on energy and exergy analysis. The results show that the average coefficient of performance (COP) of the CCHP system is 1.19 in summer and 1.42 in winter, and the average exergy efficiencies are $46 \%$ and $47 \%$ under normal operating conditions. It can also be concluded that both the current density and operating temperature have significant effects on the energy performance of the CCHP system, while only the current density affects the exergy performance noticeably. The ambient temperature can affect both the energy and exergy performance of the CCHP system. This system has the advantages of high facility availability, high efficiency, high stability, low noise and low emission; it has a good prospect for residential applications.
\end{abstract}

\footnotetext{
*Correspondence: zhongminwan@hotmail.com, zhongminwan.hust@gmail.com tuzhengkai@163.com
} 


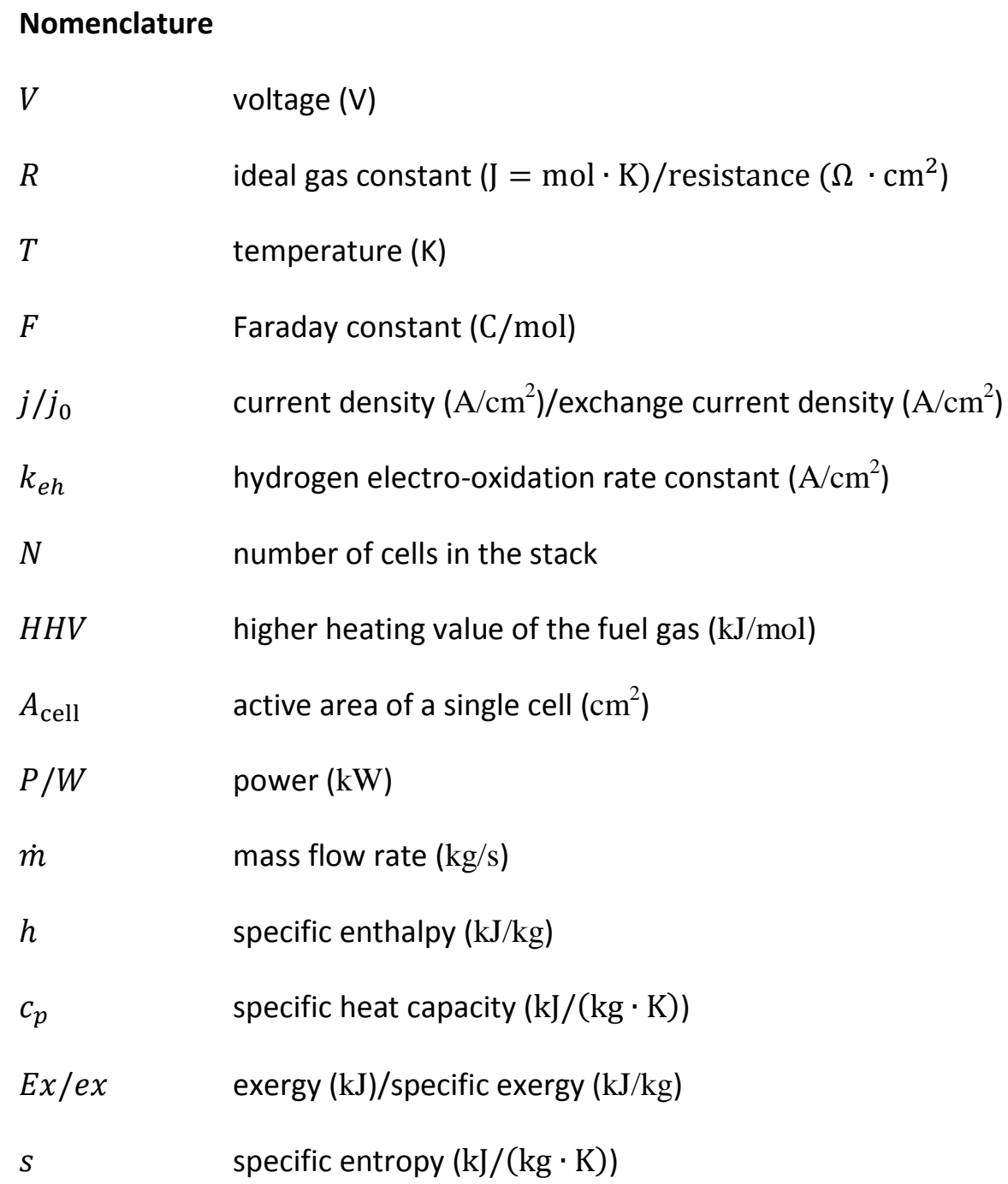




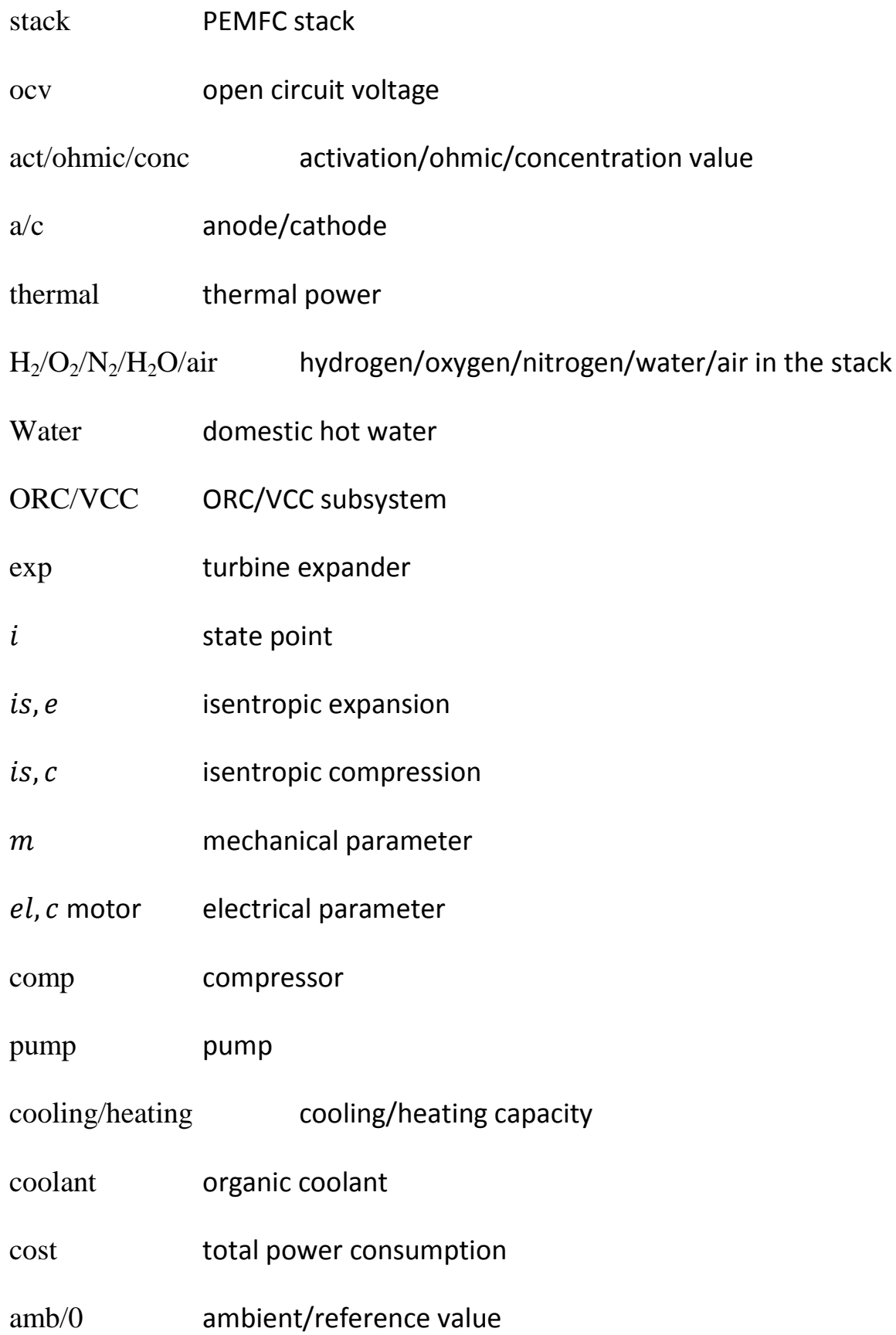




\section{Introduction}

CCHP and combined heating and power (CHP) technology are effective and widely used ways to improve energy utilization, especially in the field of low grade thermal energy utilization [1-3]. Fuel cell-based CCHP/CHP systems have attracted much attention in recent decades due to their excellent performance of high efficiency, high stability, low noise and low emission [4,5]. Another effective way to make the most of the low-grade thermal energy is to introduce an ORC system [6]. The low grade energy used in an ORC system can be derived from different sources, such as waste heat from internal combustion engines [7], low temperature energy of liquefied natural gas engines [8], solar energy $[9,10]$, biomass combustion energy [11], exhaust heat from gas turbines [12] and fuel cells $[13,14]$.

With respect to fuel cell-based CHP technology, Korsgaard et al. [15] designed a high-temperature PEMFC-based micro-CHP system combined with the steam-reforming reactor, burner and a thermal storage system. A simplified complete model was also developed and implemented in the Matlab/Simulink environment. Mamaghani et al. [16] developed a predictive model and an adaptive long-term performance multi-objective optimization approach for high-temperature PEMFC-based CHP system. Net electrical efficiency, thermal generation, and electrical power generation were selected as the objective functions. The comparative study showed that the electrical efficiency of the CHP system can be remarkably improved with the obtained optimal points from multi-objective optimization approach, especially at longer lifetimes. In their previous studies, participation strategy and recovery strategy were proposed to improve the excursion of thermal and electrical generation of the CHP system from the steady state production [17]. Barelli et al. [18] presented a PEMFC-based CHP system and evaluated the dynamic performance in the Matlab/Simulink environment. Efficiency, fuel consumption, hot water production and response time were thoroughly investigated. Oh et al. [19] conducted a series of studies aimed at obtaining the optimal operation strategy for a $1 \mathrm{~kW}$ PEMFC-based CHP system for residential applications. With an optimal operation strategy, the costs could be reduced by $20 \%$. The design options for fuel cell-based CHP systems in residential applications were carried out with optimization work by Adam et al. [20]. Optimization study of efficiency and membrane area and sensitivity analysis were conducted on a $5 \mathrm{~kW}$ PEMFC-based micro-CHP system by Marcoberardino et al. [21]. Xie et al. [22] designed a $1 \mathrm{~kW}$ PEMFC-based residential micro-CHP system and simulated the energy and exergy performance of the system by means of Aspen Plus. The effects of operating conditions on the system performance were also analyzed in detail. Arsalis et al. [23] conducted a modeling study on hightemperature PEMFC-based micro-CHP systems and heat pump assisted high-temperature PEMFC-based micro-CHP systems for residential applications with a total system efficiency of $81.5 \%$.

In the field of fuel cell-based CCHP technology, Facci et al. [24] studied the technical and economic performances of a CCHP system based on solid oxide fuel cells (SOFC). System efficiency, primary energy consumption reduction and payback period were analyzed. In addition, some optimization studies on the design and control strategies of CCHP system were also conducted. Calise et al. [25] studied the dynamic behavior of a PEMFC-based CCHP system combined with solar energy and a $\mathrm{LiBr}-\mathrm{H} 2 \mathrm{O}$ absorption chiller using TRNSYS. The results showed that the total performance of the CCHP system was closely related to the PEMFC operating conditions, and could be improved with higher operating temperatures and higher electrical efficiency. Chen et al. [4] designed a PEMFCbased CCHP system combined with a single stage absorption chiller. A complete model including the 
fuel cell stack, gas supply system, $\mathrm{LiBr}-\mathrm{H} 2 \mathrm{O}$ absorption chiller, and system efficiency was developed. However, the energy consumption inside the system was ignored. Solar energy was added to the CCHP system in their another work with a maximum efficiency of $81 \%$ [26]. In addition, energy consumption inside the system has been taken into consideration in their work. Chang et al. [27] developed a residential micro-CCHP based on solar energy and PEMFC consisting of a PEMFC subsystem, an ORC subsystem and a VCC subsystem. In view of the instability of solar energy, this micro-CCHP will reduce to a PEMFC-based CCHP system with little or even without solar energy.

With regards to ORC systems, the selection of appropriate working fluids is an important aspect. Da et al. [28] put forward a simple way to predict the optimum design and operation parameters for single stage axial expanders. The results showed that the effect of the working fluids on the efficiency maps should not be ignored. Wang et al. [29] developed a thermodynamic model for a single stage ORC system to recycle low-grade thermal energy. The system efficiency with R123, R245fa and R600a as the working fluids were analyzed and compared. Wei et al. [30] developed a dual-loop ORC system to recover the engine waste heat at a relatively high-temperature. Energyand exergy-based working fluid selection was conducted on R124, R134a, R245fa, R600, R600a and R1234yf; the results showed that R1234yf was the best one for high operating loads. Different working fluids including cyclopentane, C5F12, R365mfc, R245ca and R601a were collected and analyzed to recycle waste heat with the temperature of $373-423 \mathrm{~K}$ based on thermal optimization by Cataldo et al. [31]. Najaf et al. [32] studied R245ca and nine other working fluids by means of performance analysis and sensitivity analysis. Exergy-based fluid selection of R227ea, R600a, R245fa and R601a for a geothermal energy utilization ORC system was also conducted by Heberle and Brüggemann [33]. Liu et al. [34] analyzed the performance of an ORC system for geothermal energy utilization using R600a/R601a mixtures as the working fluid. R600a and R134a were analysed for the ORC system to recycle waste heat with a temperature of 403-453 K. Nasir and Kim [35] developed an integrated system combined with ORC and VCC systems for residential applications. In this integrated system, the ORC system was the prime mover and drove the VCC system for air conditioning. Qiu [36] collected various working fluids for ORC and analyzed the effects of working fluids on a micro-CHP system. An appropriate organic fluid should be selected with consideration made for boiling temperature, enthalpy drop, heat transfer characteristics, thermal and chemical stability, low cost and so on according to a specific heat source.

In the fields of fuel cell-based ORC system, Tuo [37] and Al-Sulaimana et al. [38] both individually designed CCHP systems based on SOFC combined with an ORC system, and the efficiency was considerable. However, the operating temperatures of both the systems were very high and not suitable for residential applications. Aminyavari et al. [39] developed an internal-reforming SOFC-gas turbine hybrid system integrated with the ORC system, and studied the exergetic, economic and environmental performance. The results showed that the ORC system could enhance the exergetic efficiency by $8.84 \%$. Ebrahimi and Moradpoor [40] developed another kind of CHP system combined with SOFC, micro gas turbine and ORC system. Thermodynamic analysis and sensitivity analysis were conducted; the results show that the efficiency of the micro-CHP system can reach more than $65 \%$.

The coolant temperature of high-temperature PEMFC can be as high as $383-453 \mathrm{~K}$, which is very suitable for recovery by ORC system integrated into a micro-CCHP system. As has been reviewed above, most PEMFC-based CCHP systems were composed of an absorption chiller. On one hand, absorption chiller can only provide cooling capacity in summer, it is idle in winter and extra energy 
system is often needed for residential use. While the VCC system can work properly both in summer and in winter with a four-way reversing valve. On the other hand, the energy efficiency of an absorption chiller is much lower than that of a VCC system. As a result, both the economic performance and thermal performance of CCHP systems combined with a VCC system are better than those of conventional ones. With this mind, a novel high-temperature PEMFC-based microCCHP system combined with an ORC and a VCC subsystem is proposed. Six working fluids, i.e., C5F12, C4H5F5 (R365mfc), C5H12 (iso-pentane, R601a), C5H12 (n-pentane, R601), C5H10 (cyclopentane) and C3H3F5 (R245ca) are contrastive investigated by means of Matlab coupled with REFPROP. With the selected working fluid, the COP and the exergy efficiency of the novel CCHP system are analyzed in detail.

\section{Micro-CCHP system description}

High-temperature PEMFC is the prime mover of the proposed micro-CCHP system. An ORC subsystem is adapted to recycle the waste heat of the PEMFC stack and output mechanical power. The VCC subsystem is driven by the mechanical power from the ORC subsystem and produces cooling capacity in summer and heating capacity in winter. The schematic diagram of the microCCHP system is shown in Fig. 1.

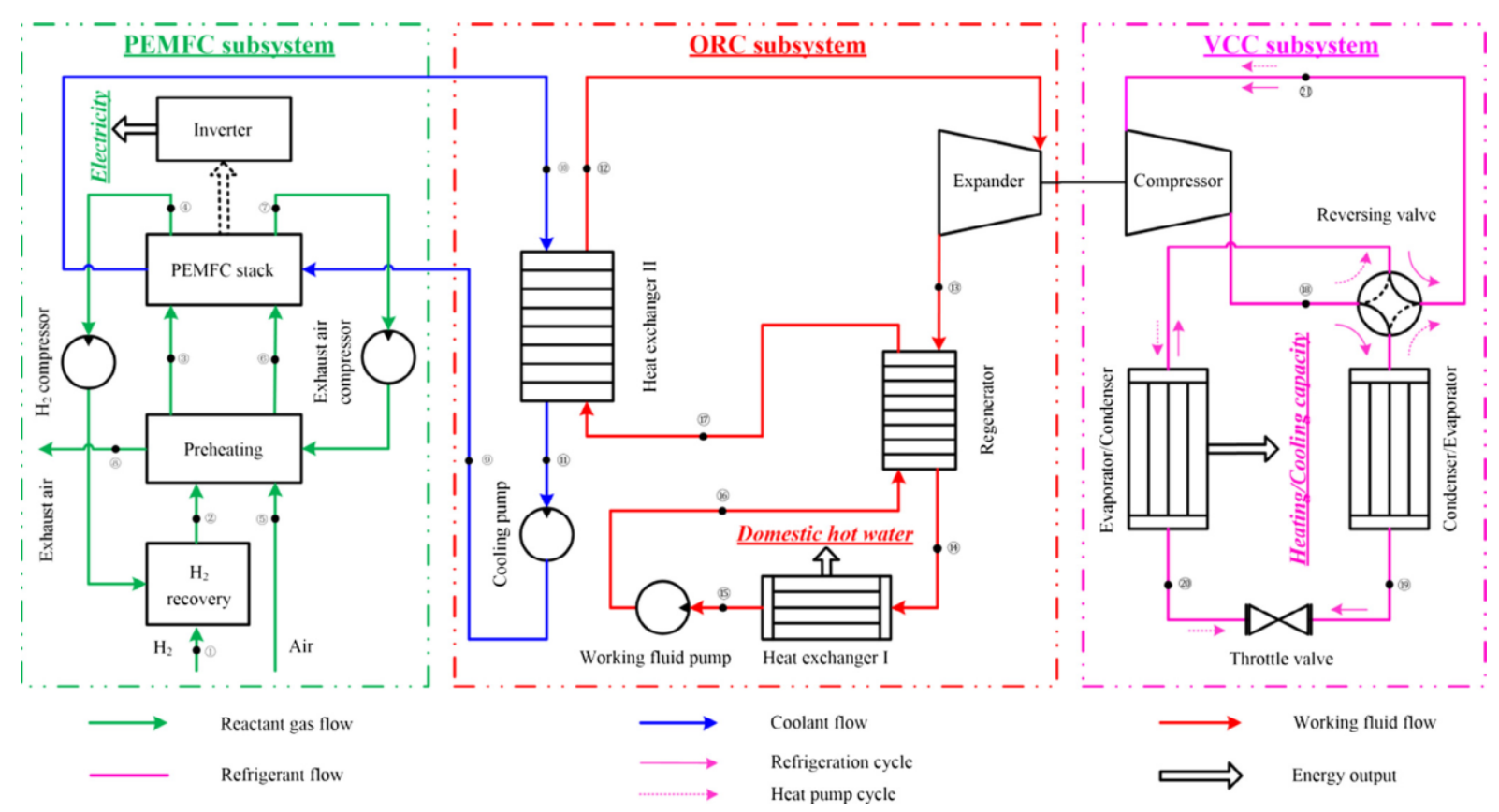

Figure 1 Schematic of the proposed micro-CCHP system.

In the PEMFC subsystem, the cathode and the anode are fed with air and pure hydrogen, respectively. The reactant gas is preheated in the preheater by the tail gas from the cathode. The inlet reactant gas temperature is $10 \mathrm{~K}$ lower than the tail gas temperature, which is equal to the operating temperature. It should be noted that the tail gas from the anode is recycled, so the hydrogen utilization ratio is regarded as $100 \%$. The coolant of the PEMFC subsystem is coolant oil and the hot coolant oil is sent to the ORC subsystem to generate superheated vapor. 
The core component of the ORC subsystem is the turbine expander. Quasi-isentropic expansion process of the superheated vapor with high-temperature and high pressure from the heat exchanger II takes place in the turbine expander and output mechanical power. Then, the exhaust vapor flows through the regenerator and the heat exchanger I. Waste heat of the ORC subsystem is recycled at the heat exchanger I to produce domestic hot water. The output power of the turbine expander is transmitted to the VCC subsystem to drive the compressor.

The VCC subsystem is a single-stage vapor compression cycle and the refrigerant is R290. This subsystem can achieve both refrigeration cycle and heat pump cycle with a four-way reversing valve.

\section{Modeling methodology}

\subsection{PEMFC subsystem modeling}

The stack consists of 130 single cells with the assumption that the fuel cell stack works at steady state. The design and operating parameters are shown in Table 1.

Table 1

Design and operating parameters of the fuel cell stack.

\begin{tabular}{lll}
\hline Parameter & Value & Unit \\
\hline Number of cells $N$ & 130 & - \\
Operating temperature & 433 & $\mathrm{~K}$ \\
Current Density & 0.85 & $\mathrm{~A} / \mathrm{cm}^{2}$ \\
Inlet/outlet pressure in anode & $1 / 1$ & atm \\
Inlet/outlet pressure in cathode & $1 / 1$ & $\mathrm{~atm}$ \\
Hydrogen/air stoichiometry & $1.15 / 3$ & - \\
Inlet gas temperature & 423 & $\mathrm{~K}$ \\
Single cell active area & 200 & $\mathrm{~cm}^{2}$ \\
\hline
\end{tabular}

The single cell voltage Vcell can be calculated with consideration of the activation overpotential, $V_{\text {act }}$ and ohmic overpotential, $V_{\text {ohmic }}$ :

$V_{\text {cell }}=V_{\text {ocv }}-V_{\text {act }}-V_{\text {ohmic }}$

Overpotentials can be calculated as follows $[15,41]$ :

$V_{\text {act }}=\frac{R T_{\text {cell }}}{\alpha_{a} F} \sinh ^{-1}\left(\frac{j}{2 k_{\mathrm{eh}} \theta_{H_{2}}}\right)+\frac{R T_{\text {cell }}}{4 \alpha_{c} F} \ln \left(\frac{j+j_{0}}{j_{0}}\right)+R_{\text {conc }}\left(\frac{j}{\lambda_{\text {air }}-1}\right)$

$V_{\text {ohmic }}=j \cdot R_{\text {ohmic }}$

where $V_{\mathrm{ocv}}$ is the open circuit voltage. $R$ is the ideal gas constant, $F$ is the Faraday constant, $T_{\text {cell }}$ is the operating temperature, $j$ and $j_{0}$ are the current density and exchange current density, and $k_{\text {air }}$ is the air stoichiometry. $\alpha_{a}$ and $\alpha_{c}$ are the anode and cathode charge transfer coefficient, respectively. $k_{\mathrm{eh}}$ is the hydrogen electro-oxidation rate constant, $h_{\mathrm{H}_{2}}$ is the hydrogen surface coverage. $R_{\text {conc }}$ and $R_{\text {ohmic }}$ are the concentration resistance and ohmic resistance, and can be obtained as follows [42]:

$R_{\text {conc }}=0.4306-8.203 \times 10^{4} T_{\text {cell }}$

$R_{\text {ohmic }}=0.2289-1.667 \times 10^{4} T_{\text {cell }}$ 
It is assumed that the performance of each single cell in the stack is consistent when modeling the stack; therefore, the fuel cell stack voltage can be calculated as follows:

$V_{\text {stack }}=N \cdot V_{\text {cell }}$

The total electric power and thermal power of the stack can be obtained by:

$P_{\text {stack }}=V_{\text {stack }} \cdot j \cdot A_{\text {cell }}$

$P_{\text {thermal }}=N \cdot\left(\frac{H H V}{2 F}-V_{\text {cell }}\right) \cdot j \cdot A_{\text {cell }}$

where $A_{\text {cell }}$ is the single cell active area and $H H V$ is the higher heating value of the fuel gas.

The heat transferred to the coolant oil can be calculated by Eq. (9), which ignores the heat exchange between the stack and the surroundings.

$P_{\text {coolant }}=P_{\text {thermal }}-P_{\mathrm{H}_{2}}-P_{\mathrm{O}_{2}}-P_{\mathrm{N}_{2}}-P_{\mathrm{H}_{2} \mathrm{O}}$

where $P_{\mathrm{H}_{2}}, P_{\mathrm{O}_{2}}, P_{\mathrm{N}_{2}}$ and $P_{\mathrm{H}_{2} \mathrm{O}}$ represent the heat carried out through the anode tail gas (hydrogen), cathode tail gas (oxygen and nitrogen) and water, respectively.

The constants and empirical parameters used in the PEMFC model are shown in Table 2.

Table 2

Constants and empirical parameters used in the PEMFC model.

\begin{tabular}{lll}
\hline Parameter & Value & Unit \\
\hline Open circuit voltage $V_{\text {ocv }}$ & 0.95 & $\mathrm{~V}$ \\
Ideal gas constant $R$ & 8.314 & $\mathrm{~J} /(\mathrm{mol} \cdot \mathrm{K})$ \\
Faraday constant $F$ & 96485.3 & $\mathrm{C} / \mathrm{mol}$ \\
Exchange current density $j_{0}$ & $2.01926 \times 10^{4}$ & $\mathrm{~A} / \mathrm{cm}^{2}$ \\
Anode/ Cathode charge transfer coefficient & $0.5 / 0.25$ & - \\
$\quad \alpha_{a} / \alpha_{c}$ & & \\
Hydrogen electro-oxidation rate constant $k_{\text {eh }}$ & 1.63818 & $\mathrm{~A} / \mathrm{cm}^{2}$ \\
Hydrogen surface coverage $\theta_{\mathrm{H}_{2}}$ & 0.14212 & - \\
Higher heating value of hydrogen $H H V$ & 282.63 & $\mathrm{~kJ} / \mathrm{mol}$ \\
\hline
\end{tabular}

\subsection{ORC subsystem modeling}

In the ORC subsystem, the working fluid temperature at the outlet of the heat exchanger II is set as $5 \mathrm{~K}$ lower than the inlet temperature of the hot coolant oil. The superheat temperature is $10 \mathrm{~K}$ at the inlet of the turbine expander. The working fluid temperature at the outlet of the heat exchanger $\mathrm{I}$ is set as $305 \mathrm{~K}$, and the overcooling temperature is $5 \mathrm{~K}$.

The thermal energy carried out by the organic working fluid can be calculated as:

$P_{\text {coolant }}=\dot{m}_{\mathrm{ORC}}\left(h_{12}-h_{17}\right)$

The output power of turbine expander can be calculated as:

$W_{\text {exp }}=\dot{m}_{\mathrm{ORC}}\left(h_{12}-h_{13}\right)$

The specific enthalpy of the vapor at the outlet of the turbine expander can be obtained as:

$h_{13}=\left(1-\eta_{i s, e}\right) h 12+\eta_{i s, e} h_{13, s}$ 
where $\eta_{i s, e}$ is the isentropic expansion coefficient of the turbine expander with a value of 0.85 .

The energy balance in the regenerator can be expressed as:

$h_{17}-h_{16}=h_{13}-h_{14}$

The heat recovery from the heat exchanger I can be calculated as:

$\dot{Q}_{\text {water }}=\dot{m}_{\mathrm{ORC}}\left(h_{14}-h_{15}\right)$

where $\dot{m}_{\mathrm{ORC}}$ represents the organic working fluid mass flow rate. $h_{i}$ is the specific enthalpy of the organic working fluid at state point $i$. This definition is also applied in the VCC subsystem.

\subsection{VCC subsystem modeling}

A single stage VCC system is adopted in the CCHP system and the pressure-enthalpy diagram is shown in Fig. 2. The black numbers 19 and 20 are the refrigeration cycle state points, and the blue numbers 20 and 19 in the bracket are the heat pump cycle state points. Numbers 18, 18s and 21 are the shared state points. Condensation temperature is set as $8 \mathrm{~K}$ higher than the ambient temperature in summer, and evaporation temperature is set as $10 \mathrm{~K}$ lower than the ambient temperature in winter.

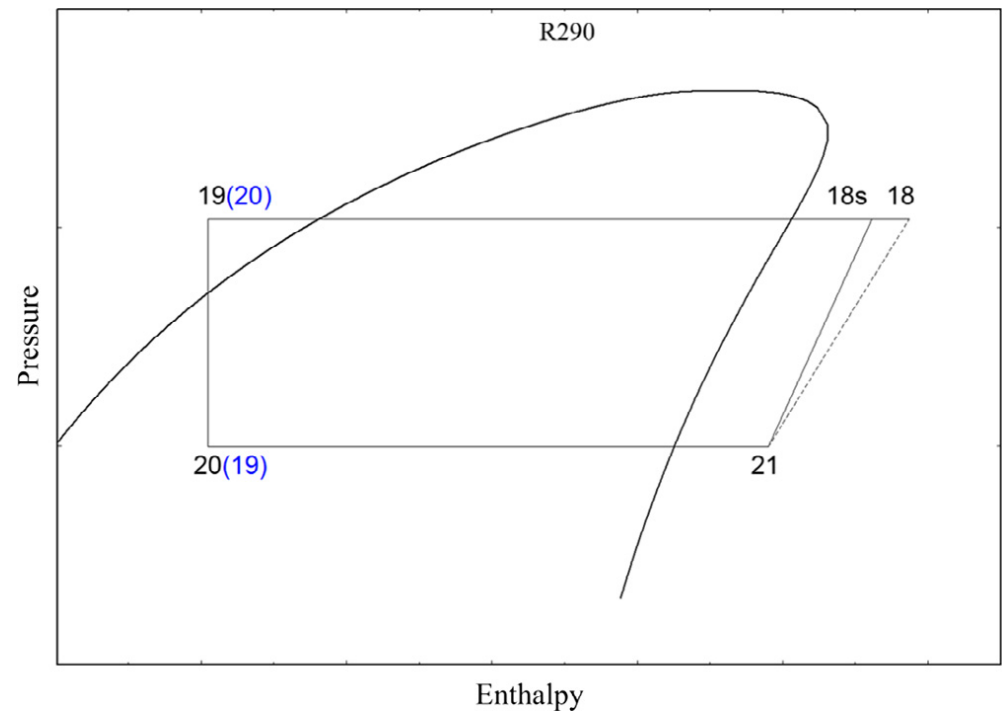

Figure 2 Pressure-enthalpy diagram of VCC subsystem.

The compressor is driven by the output power of the turbine expander:

$W_{\text {comp }}=W_{\text {exp }}$

The refrigerant mass flow rate can be obtained as:

$W_{\text {comp }}=\dot{m}_{\mathrm{VCC}}\left(h_{18}-h_{21}\right)$

where the specific enthalpy of the vapor at the outlet of the compressor can be obtained as:

$h_{21}=h_{18, s}-\eta_{i s, c}\left(h_{18}-h_{21}\right)$ 
where $\eta_{i s, c}$ is the isentropic compression coefficient of the compressor with a value of 0.85 .

The cooling capacity in refrigeration model can be calculated as:

$\dot{Q}_{\text {cooling }}=\dot{m}_{\mathrm{VCC}}\left(h_{21}-h_{20}\right)$

The heating capacity in heat pump model can be calculated as:

$\dot{Q}_{\text {heating }}=\dot{m}_{\mathrm{VCC}}\left(h_{18}-h_{20}\right)$

\subsection{Balance-of-plant modeling}

In the balance-of-plant modeling, the properties of the cathode tail gas are regarded as the same as those of air. Hydrogen and air are treated as ideal gases. Therefore, the energy cost of the hydrogen compressor and the exhaust air compressor can be calculated as:

$P_{\text {comp }}=\dot{m}_{5} c_{p, i} T_{i}\left(\beta_{c, i}^{\frac{\kappa_{i}-1}{\kappa_{i}}}-1\right) \frac{1}{\eta_{i s, c} \cdot \eta_{m} \cdot \eta_{e l, c}}$

where subscript $i$ represents $\mathrm{H}_{2}$ and Air. $c_{p, i}$ is the specific heat capacity at the outlet of the stack, $\beta_{c, i}$ is the compression rate. $\kappa_{i}$ is the isentropic exponents. $T_{\mathrm{H}_{2}}$ in this formula is $T_{4}$ and $T_{\text {air }}$ is $T_{7}$. $\eta_{i s, c}, \eta_{m}$ and $\eta_{e l, c}$ are the isentropic compression efficiency, mechanical efficiency and motor efficiency of the compressor with the values of $0.7,0.8$ and 0.9 , respectively.

The circulating pump power of for ORC subsystem and the PEMFC subsystem can be calculated as:

$P_{\text {pump }, \text { ORC }}=\dot{m}_{\mathrm{ORC}}\left(h_{16}-h_{15}\right)$

$P_{\text {pump,PEMFC }}=\frac{\dot{m}_{\text {oil }}}{\rho_{\text {oil }}}\left(p_{9}-p_{11}\right)$

where $\dot{m}_{\text {oil }}$ and $\rho_{\text {oil }}$ are the mass flow rate and density of the coolant oil, respectively. $\left(p_{9}-p_{11}\right)$ is the total pressure drop of the coolant oil in the stack and the heat exchanger II.

The total energy cost of the CCHP system is:

$P_{\text {cost }}=\sum P_{\text {comp }, i}+P_{\text {pump }, \mathrm{ORC}}+P_{\text {pump }, \mathrm{PEMFC}}$

\subsection{Exergy analysis}

Exergy is the maximum amount of work that can be produced from working vapor, heat or a material brought to equilibrium with the environment. It is often used to evaluate the energy quality. The exergy of a vaporized material is composed of physical exergy and chemical exergy.

$$
\begin{aligned}
& E x_{P H}=\dot{m}\left[\left(h-h_{0}\right)-T_{0}\left(s-s_{0}\right)\right] \\
& E x_{C H}=\dot{m} \cdot \frac{e x_{C H}}{M}
\end{aligned}
$$

where $\dot{m}$ is the mass flow rate of the reactant gas, $h$ and $s$ are the specific enthalpy and entropy under the working conditions, $h_{0}$ and $s_{0}$ are the specific enthalpy and entropy at ambient temperature $T_{0}$, respectively. $e x_{C H}$ is the standard chemical exergy and $M$ is its molecular weight. 
The heat exergy can be calculated by:

$E x_{Q}=Q \cdot\left(1-T_{0} / T\right)$

where $Q$ is the heat amount of the heat steam and $T$ is the temperature of the working condition.

\subsection{Performance analysis of the CCHP system}

The coefficient of performance of the CCHP system is defined as the ratio of the total output energy to the total input energy:

COP $=\frac{\left(P_{\text {stack }}-P_{\text {cost }}\right)+\dot{Q}_{\text {water }}+\dot{Q}_{\text {cooling }}+\dot{Q}_{\text {heating }}}{\left(P_{\text {stack }}+P_{\text {thermal }}\right)}$

where $\left(P_{\text {stack }}-P_{\text {cost }}\right)$ is the actual output electric power, $\left(P_{\text {stack }}+P_{\text {thermal }}\right)$ is the total input energy. $\dot{Q}_{\text {heating }}=0$ in summer and $\dot{Q}_{\text {cooling }}=0$ in winter.

The exergy efficiency of the CCHP system is defined as the ratio of the total output exergy to the total input exergy:

$\eta_{e x}=\frac{\left(P_{\text {stack }}-P_{\text {cost }}\right)+E x_{\text {water }}+E x_{\text {cooling }}+E x_{\text {heating }}}{\left(E x_{P H}+E x_{C H}\right)}$

where $E x_{\text {water }} E x_{\text {cooling }}$ and $E x_{\text {heating }}$ are the heat exergy of the heated water, cooling capacity and heating capacity, respectively. $\left(E x_{P H}+E x_{C H}\right)$ is the total input exergy. $E x_{\text {heating }}=0$ in summer and $E x_{\text {cooling }}=0$ in winter.

\section{Results and discussions}

\subsection{Validation of the high-temperature PEMFC model}

The high-temperature PEMFC model is validated by the experimental data from Korsgaard et al. [42]. In the validation process, the single cell voltage with operating temperature of $413 \mathrm{~K}$ and $433 \mathrm{~K}$ were calculated and compared, and the results are shown in Fig. 3. As seen, the calculated single cell voltage is basically in agreement with the experimental data. The maximum error is approximately $5.89 \%$, and the average error is approximately $3.77 \%$. The consistency of the calculated value and the experimental data in the current density range of $0.25-0.85 \mathrm{~A} / \mathrm{cm}^{2}$ is very high, which means that the high-temperature PEMFC model is applicable and reliable in the following modeling study. 


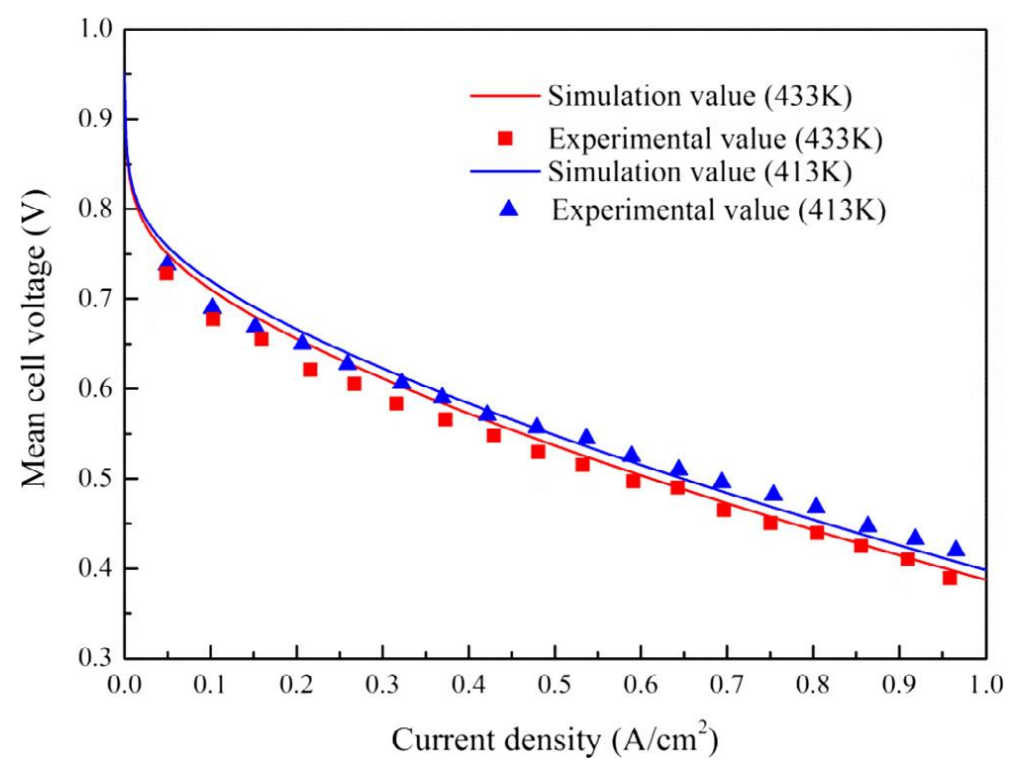

Figure 3 Validation of the high-temperature PEMFC model.

\subsection{Effects of current density and operating temperature on PEMFC}

Fig. 4 shows that the electric power and the thermal power of the stack vary with the current density and operating temperature. Since the cell voltage varies almost linearly with the current density in the range of $0.1-0.9 \mathrm{~A} / \mathrm{cm}^{2}$ (seen in Fig. 3), the electric power shows a parabolic relation with the current density in the same range. The electric power of this stack at $0.85 \mathrm{~A} / \mathrm{cm}^{2}$ is approximately $8.11 \mathrm{~kW}$ (seen in Fig. 4(a)). It can be seen from Eqs. (6) - (8) that the total energy of the stack changes linearly with the current density, as a result, the thermal power increases sharply with a large current density when the electric power increases slowly. The thermal power of this stack at $0.85 \mathrm{~A} / \mathrm{cm}^{2}$ is approximately $24.54 \mathrm{~kW}$. As shown in Fig. 4(b), both the electric power and the thermal power of the stack only change a little with the operating temperature which means that the operating temperature is not a sensitive factor to the stack performance. The electric power changes from $8.29 \mathrm{~kW}$ to $8.11 \mathrm{~kW}$ with a change rate of $2.17 \%$ when the operating temperature increases from $413 \mathrm{~K}$ to $433 \mathrm{~K}$. However, at the same time, the thermal power increases from 24.37 $\mathrm{kW}$ to $24.54 \mathrm{~kW}$ with a change rate of $0.70 \%$.
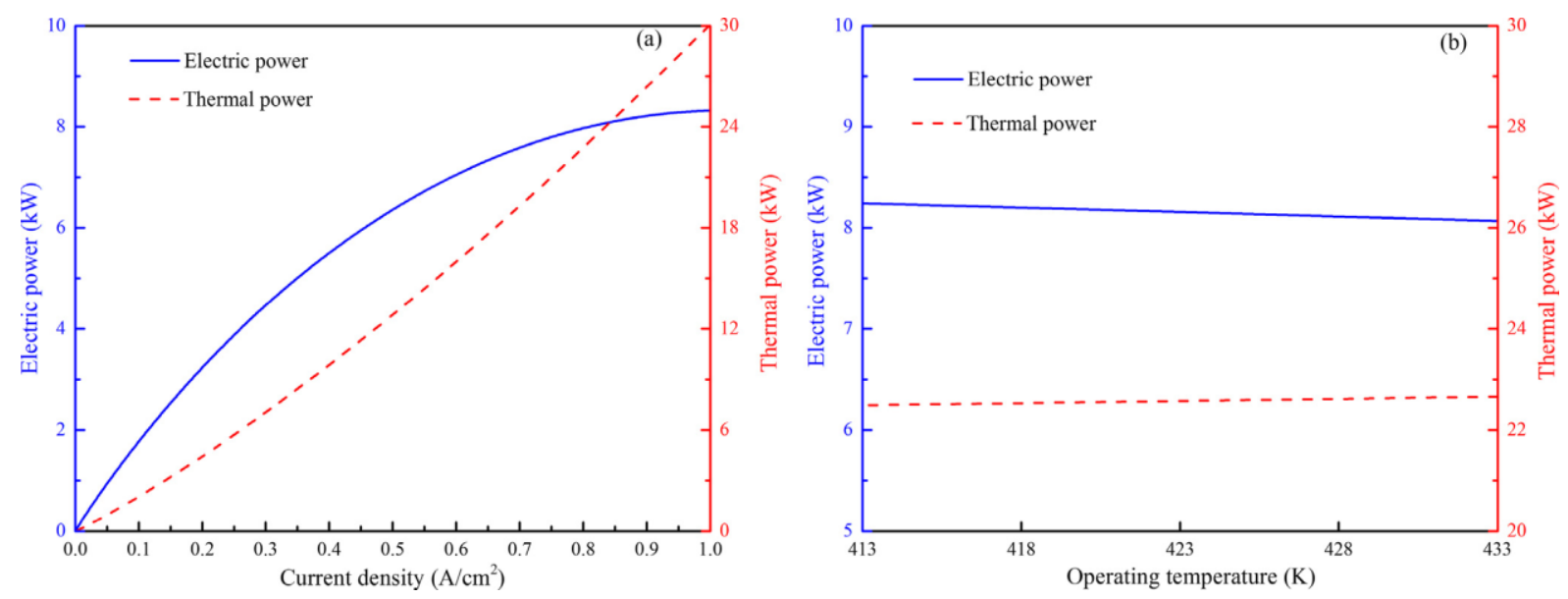

Figure 4 Electric and thermal power varies with current density (a) and operating temperature (b).

\subsection{Energy- and exergy-based working fluid selection for the ORC subsystem}


The organic working fluid is the medium that absorbs heat from the hot coolant oil and converts it to mechanical power in the turbine expander. Six organic working fluids are chosen for further study based on the output mechanical power, COP and exergy efficiency of the CCHP system. The physical, safety and environmental properties for the six organic working fluids are shown in Table 3.

Table 3

Physical, safety and environmental properties of different organic working fluids.

\begin{tabular}{|c|c|c|c|c|c|c|}
\hline Substance & C5F12 & $\mathrm{R} 365 \mathrm{mfc}$ & R601a & R601 & Cyclopentane & $\mathrm{R} 245 \mathrm{ca}$ \\
\hline Molecular weight $(\mathrm{kg} / \mathrm{kmol})$ & 288.03 & 148.07 & 72.15 & 72.15 & 70.13 & 134.05 \\
\hline Normal boiling temperature $(\mathrm{K})$ & 302.9 & 313.3 & 300.98 & 309.21 & 322.4 & 298.28 \\
\hline Critical temperature $(\mathrm{K})$ & 420.56 & 460 & 460.35 & 469.7 & 511.7 & 447.57 \\
\hline ASHRAE 34 Safety group & A3 & - & A3 & - & - & - \\
\hline Atmospheric life time $(y r)$ & 4100 & 8.6 & 0.01 & 0.01 & 0.01 & 6.2 \\
\hline Ozone depletion potential & 0 & 0 & 0 & 0 & 0 & 0 \\
\hline Global warming potential & 9160 & 794 & $\sim 20$ & $\sim 20$ & $\sim 20$ & 693 \\
\hline
\end{tabular}

The evaporation pressure of a working fluid will directly affect the mechanical properties of the related components, and will also significantly affect the circulating pump power. Therefore, the working fluid with lower evaporation pressure should be preferentially selected. The net output power per unit mass is defined as the difference between the output mechanical power and the circulation pump power with unit mass working fluid through the turbine expander. This parameter is an important index to evaluate the working capacity of an organic working fluid. The evaporation pressure and net output power per unit mass for the selected working fluids are shown in Fig. $\mathbf{5 .}$ Since the critical temperature of C5F12 is $420.56 \mathrm{~K}$, there will be no evaporation process when the temperature is higher than $420.56 \mathrm{~K}$. It can be seen from Fig. 5(a) that the evaporation pressure of the candidate working fluids are almost between $1 \mathrm{MPa}$ and $3 \mathrm{MPa}$ when the evaporation temperature is between $413 \mathrm{~K}$ and $433 \mathrm{~K}$. At the same evaporation temperature, the order of the evaporation pressure for different working fluids from small to large is: cyclopentane $<R 601<$ $\mathrm{R} 365 \mathrm{mfc}<\mathrm{R} 601 \mathrm{a}<\mathrm{C5F} 12<\mathrm{R} 245 \mathrm{ca}$, while the order of the net output power per unit mass from large to small is almost the same: cyclopentane > R601 > R601a > R365mfc > R2 45ca > C5F12, as shown in Fig. 5(b). It can be found from the preliminary comparison that R365mfc, R601a, R601 and cyclopentane seem to be better suited to the ORC subsystem. The following comparative studies of the effects on the whole CCHP system are mainly based on these four working fluids.
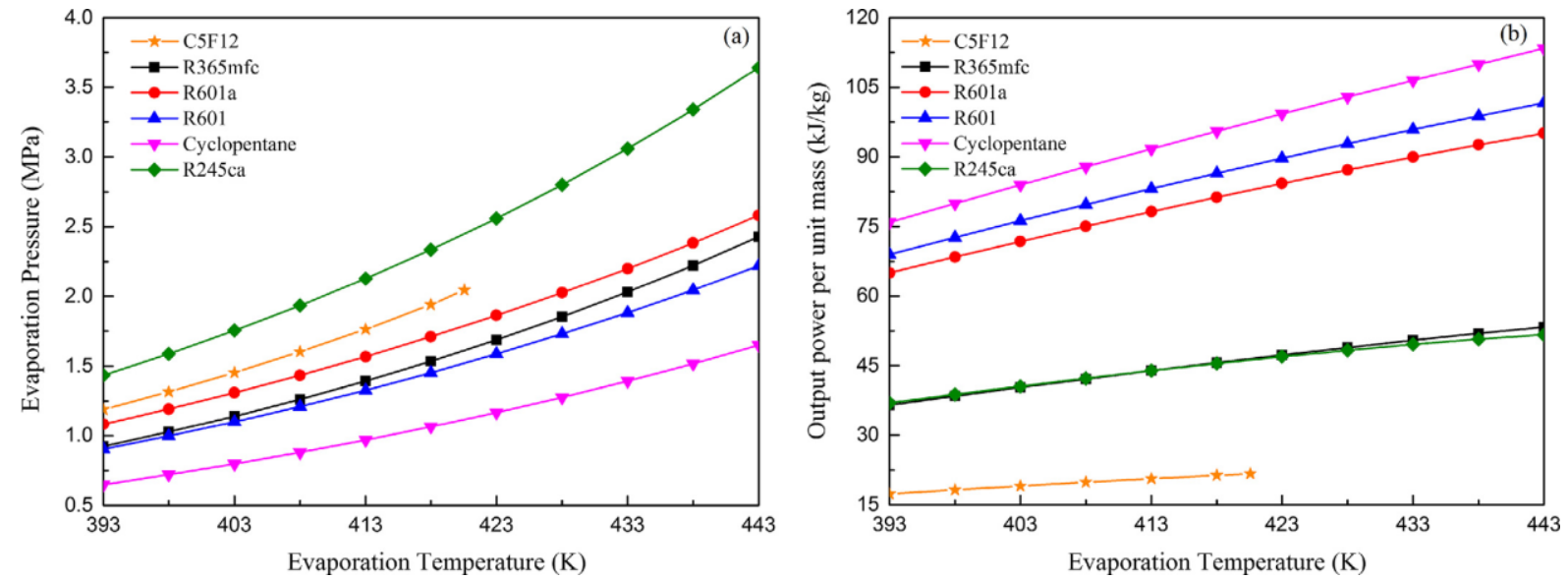

Figure 5 Evaporation pressure (a) and net output power per unit mass (b) for different working fluids.

Fig. 6 shows the output mechanical power of the turbine expander varies with current density and operating temperature for R365mfc, R601a, R601, and cyclopentane. It can be seen from Fig. 6 that the output mechanical power increases with both the current density and the operating 
temperature. That is, the lower left corner is the smallest and the upper right is the largest. The order of the output mechanical power from large to small is R601 $\approx \mathrm{R} 601 \mathrm{a}>\mathrm{R} 365 \mathrm{mfc}>$ cyclopentane. Notice that the order of the output mechanical power is not exactly the same as the order of the net output power per unit mass in Fig. $\mathbf{5}(\mathbf{b})$ due to the difference in the circulating pump power.

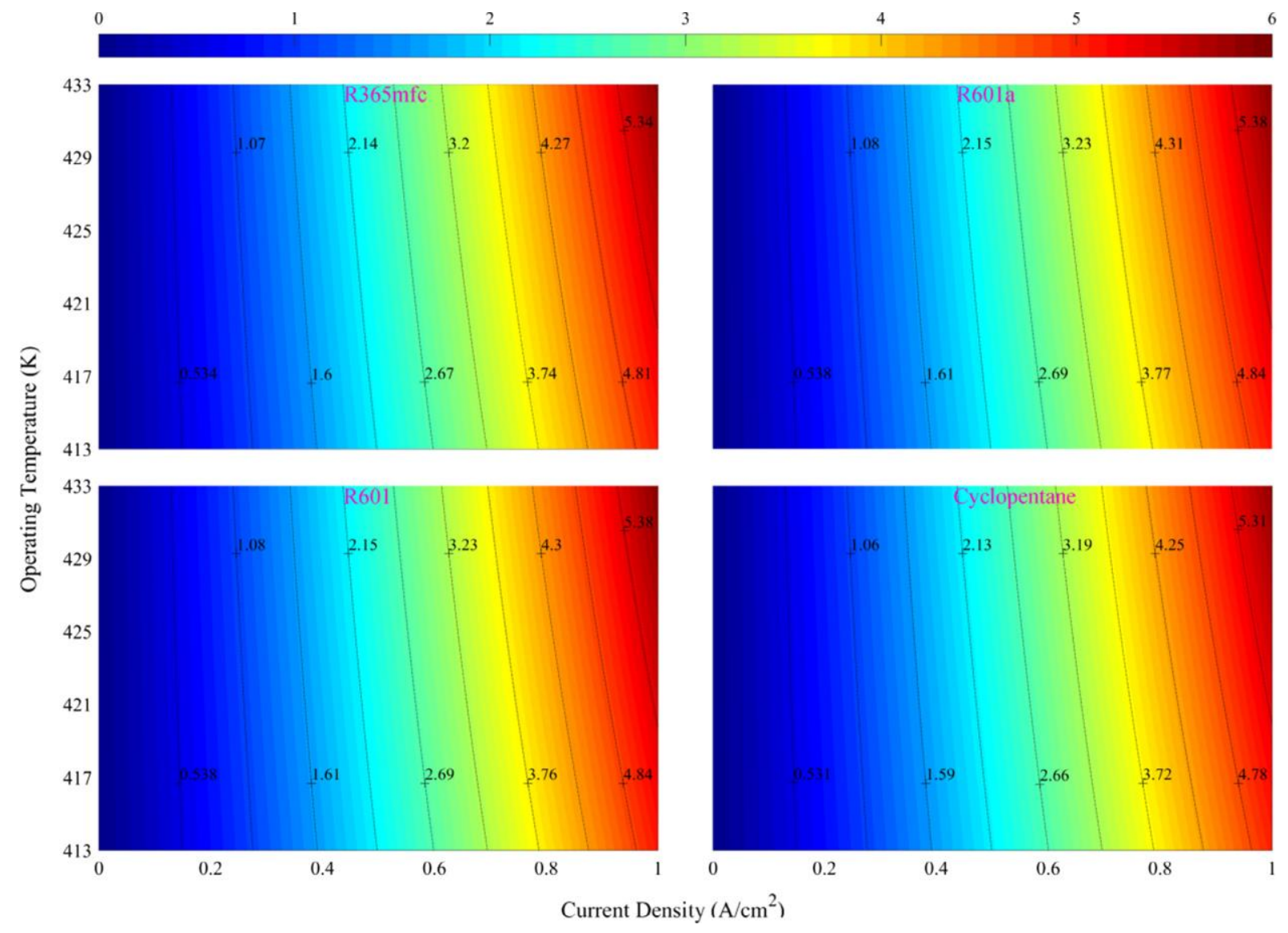

Figure 6 Contour maps of the turbine expander output mechanical power for different working fluids.

Fig. 7 shows the COP of the CCHP system varies with current density and operating temperature. Similar to the output mechanical power, the COP of the CCHP system also increases with both the current density and the operating temperature. Since the influence of working fluids on the COP is mainly reflected in the cooling/heating capacity, which is determined by the output mechanical power of the turbine expander, the variation tendency in Fig. $\mathbf{7 ( a )}$ and (b) are almost the same in summer and in winter. It should be pointed out that the COP of the CCHP system is always greater than 1.0, especially in winter, which is mainly benefiting from the VCC subsystem. 

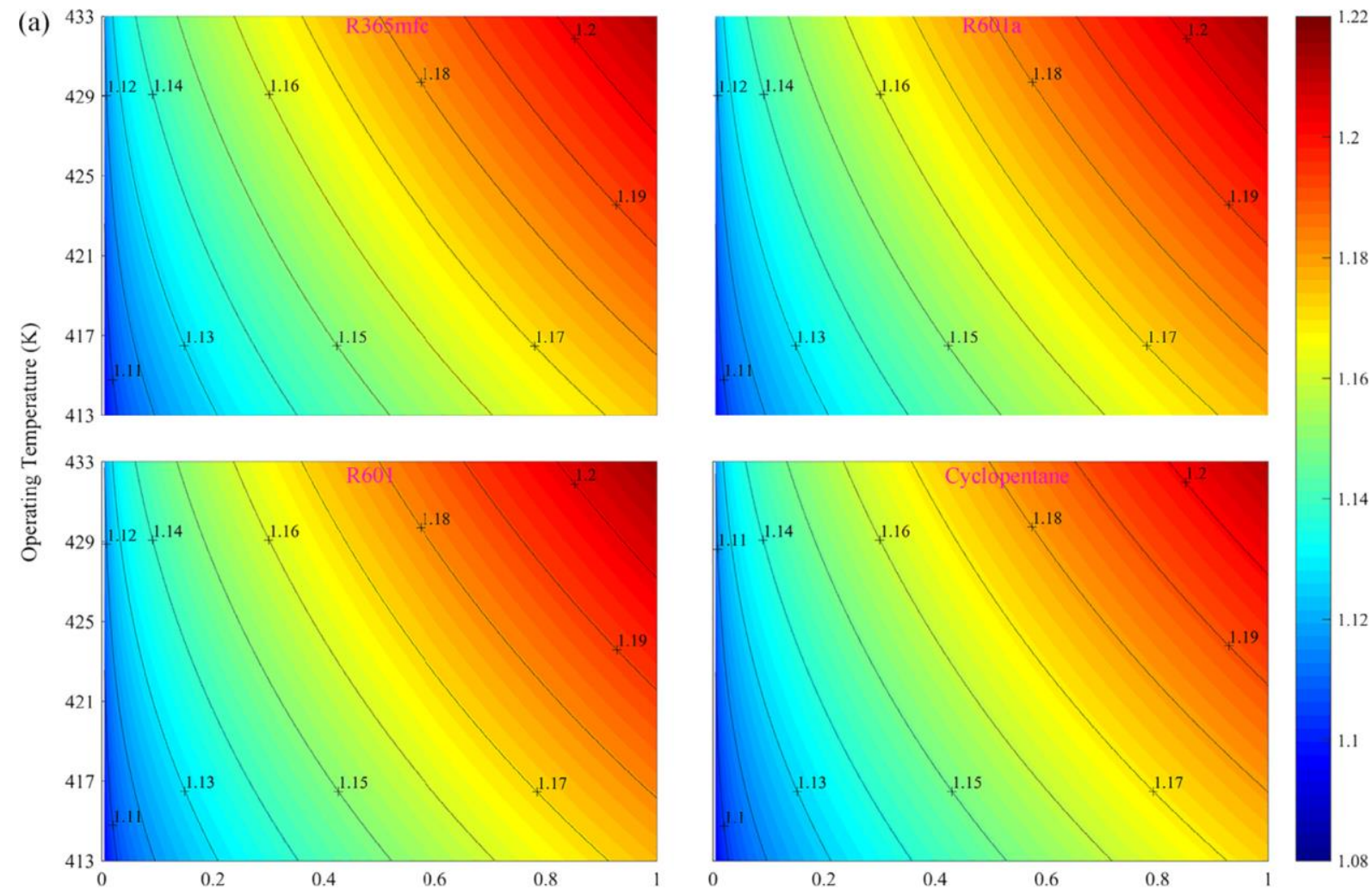

(b)

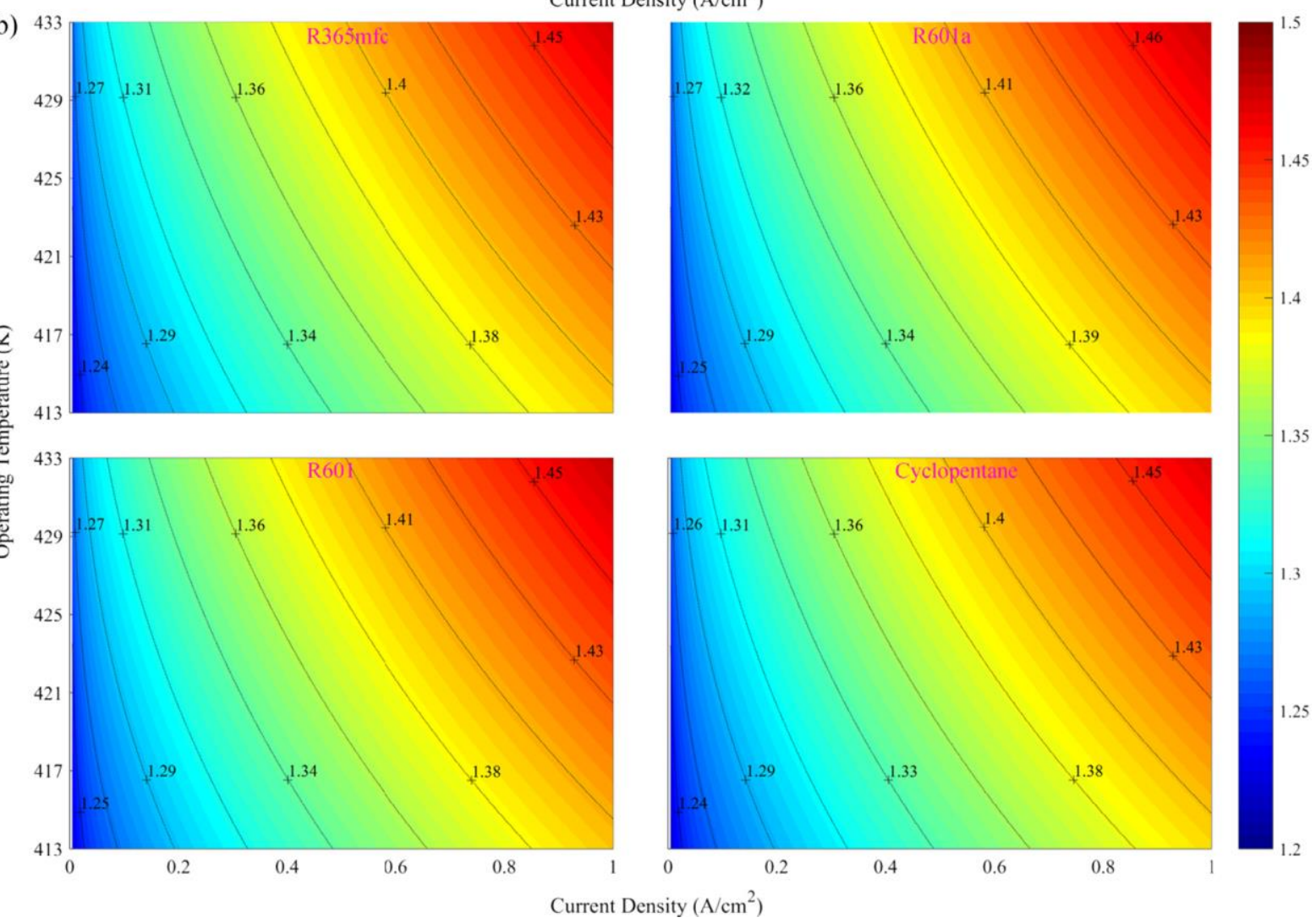

Figure 7 Contour maps of COP for different working fluids (a: In summer; b: In winter).

Fig. 8 shows the exergy efficiency of the CCHP system. It can be seen from Fig. 8 that the exergy of the CCHP system decreases along with the current density both in summer and in winter. It can be 
also seen that the exergy efficiency gradient along the operating temperature is nearly zero, which means that the exergy efficiency is almost independent of the operating temperature.
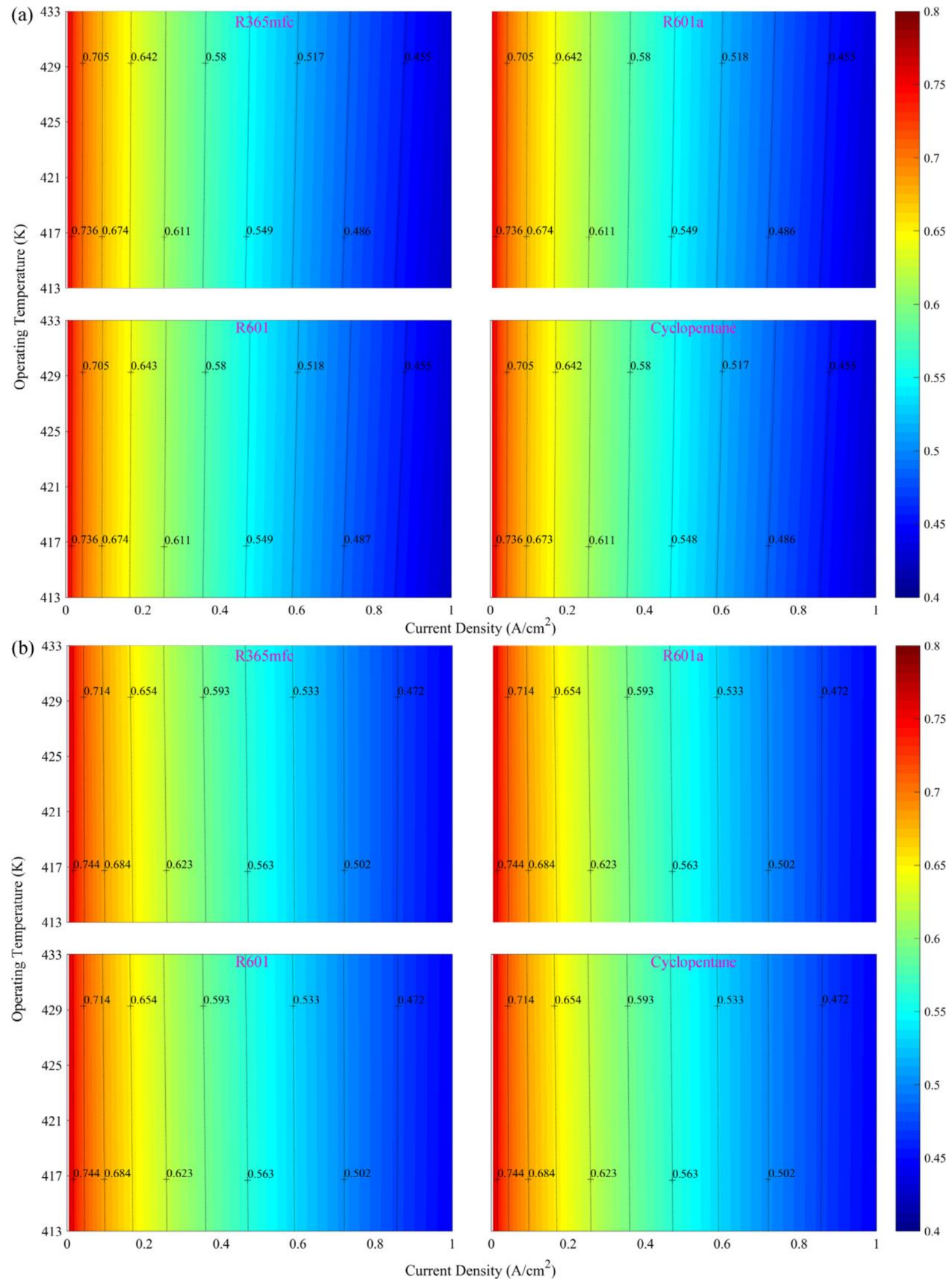

Figure 8 Contour maps of exergy efficiency for different working fluids (a: In summer; b: In winter). 
According to the comparative study on the output mechanical power of the turbine expander, the COP and the exergy efficiency of the CCHP system, R601a, R601 and cyclopentane show better cycle performance. However, the differences between these three working fluids are very small. In addition, cyclopentane is more toxic and has more potential risks. With synthetical consideration, R601 is selected in the ORC system. The following analyses are all based on R601.

\subsection{Effects of current density and operating temperature on ORC subsystem}

The effects of current density and operating temperature on the mass flow rate of the organic working fluid and the output mechanical power of the turbine expander are shown in Fig. 9. As can be seen from Fig. 9(a), the mass flow rate and the output power are approximately linear with current density. This is mainly because the mass flow rate and the output power are closely related to the thermal power transferred to the organic working fluid according to Eqs. (10) and (11), while the thermal power transferred to the organic working fluid is approximately linear with the current density according to Eqs. (8) and (9) and Fig. 4 (a). As shown in Fig. 6, the maximum output power is approximately $5.92 \mathrm{~kW}$ and the value at $0.85 \mathrm{~A} / \mathrm{cm}^{2}$ is approximately $4.83 \mathrm{~kW}$. It is showed in Fig. $\mathbf{9 ( b )}$ that the mass flow rate and the output mechanical power also change a lot with operating temperature. The mass flow rate decreases from $0.0600 \mathrm{~kg} / \mathrm{s}$ to $0.0586 \mathrm{~kg} / \mathrm{s}$ with a change rate of $2.33 \%$ and the output mechanical power increases from $4.15 \mathrm{~kW}$ to $4.83 \mathrm{~kW}$ with a change rate of $16.4 \%$. The output mechanical power significantly changes with the operating temperature mainly because the organic working fluid temperature at point 15 is directly determined by the hot coolant oil temperature, which is set as $10 \mathrm{~K}$ lower than the operating temperature.
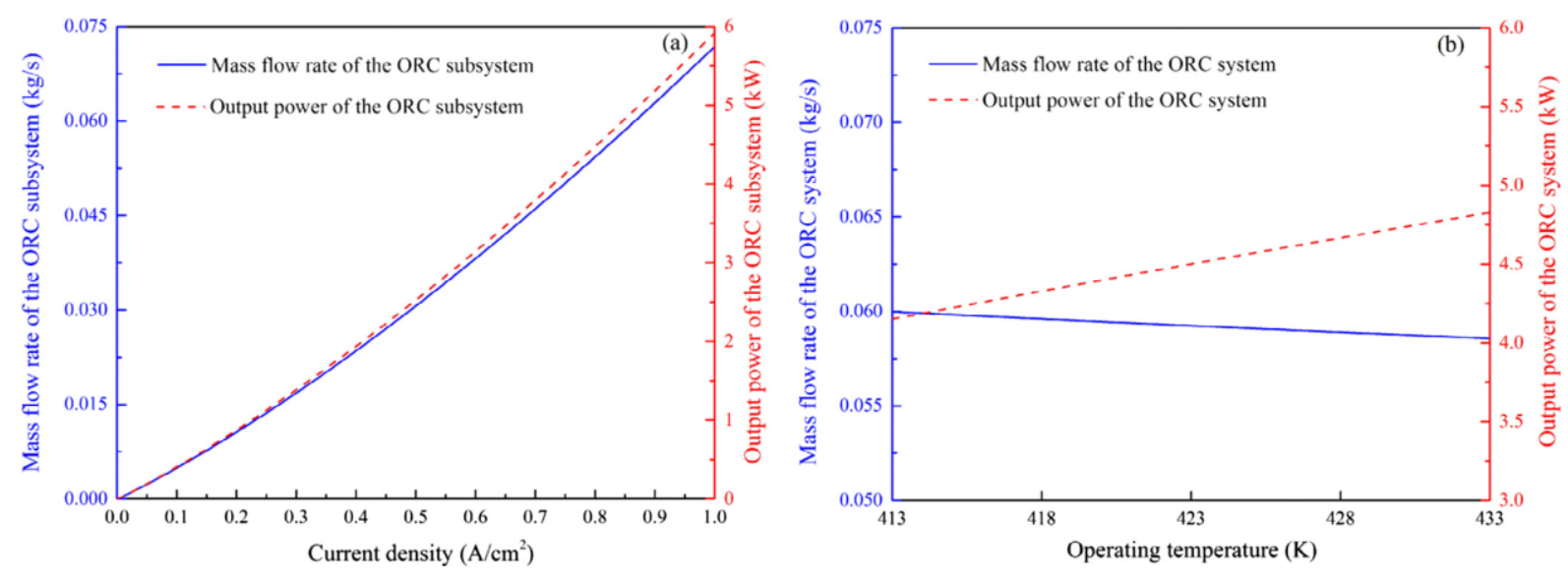

Figure 9 Performance of the ORC subsystem varies with current density (a) and operating temperature (b).

\subsection{Effects of current density and operating temperature on the total output energy}

Fig. 10 shows the effects of current density and operating temperature on the total output power of the CCHP system including electric power, cooling/heating capacity and the recovery thermal power. Since the electric power and the recovery thermal power are independent of the ambient temperature, they remain unchanged in summer and in winter. The cooling capacity only exists in summer and the heating capacity only exists in winter. As shown in Fig. 10(a), the cooling capacity and the heating capacity are consistent with the change of the output mechanical power of the turbine expander, and the recovery thermal power is consistent with the change of the thermal power of the stack. It can be seen from Fig. 10(b) that the electric power of the CCHP system is approximately $8 \mathrm{~kW}$, the recovery thermal power i.e., domestic hot water power is approximately 18 
$\mathrm{kW}$, the cooling capacity in summer is approximately $12.5 \mathrm{~kW}$ and the heating capacity in winter is approximately $20 \mathrm{~kW}$ under normal working conditions.
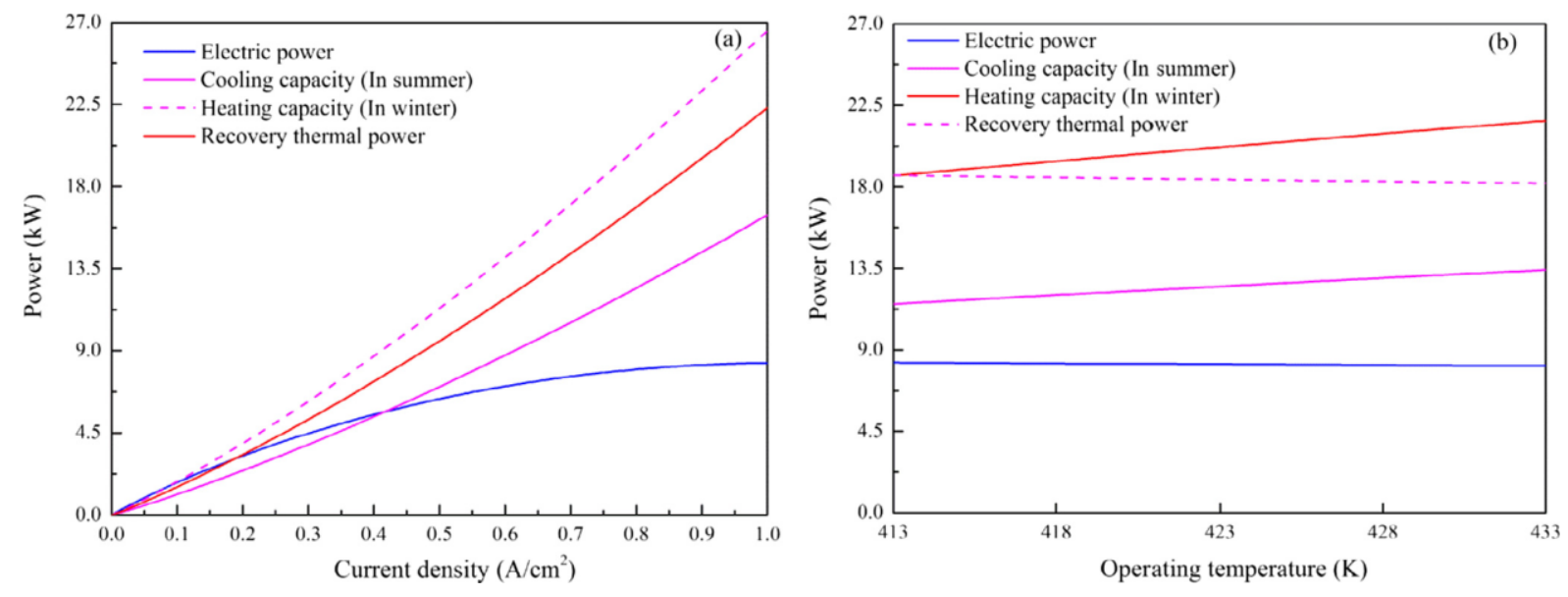

Figure 10 Output power variation with current density (a) and operating temperature (b).

\subsection{Effects of current density and operating temperature on the performance of the CCHP system}

Fig. 11 shows the COP and the exergy efficiency of the CCHP system vary with current density and operating temperature. The curves of the exergy efficiency change a little with operating temperature both in Fig. 11(a) and (b), which is in good agreement with that mentioned in Section 4.2. However, the variations of the COP with the current density and the operating temperature are more obvious. The higher the current density and the operating temperature are, the higher the COP is no matter in summer or in winter. The average COP is 1.19 , and the exergy efficiency is $46 \%$ in summer, while the COP and exergy efficiency values are 1.42 and $47 \%$ in winter under normal working conditions, respectively.
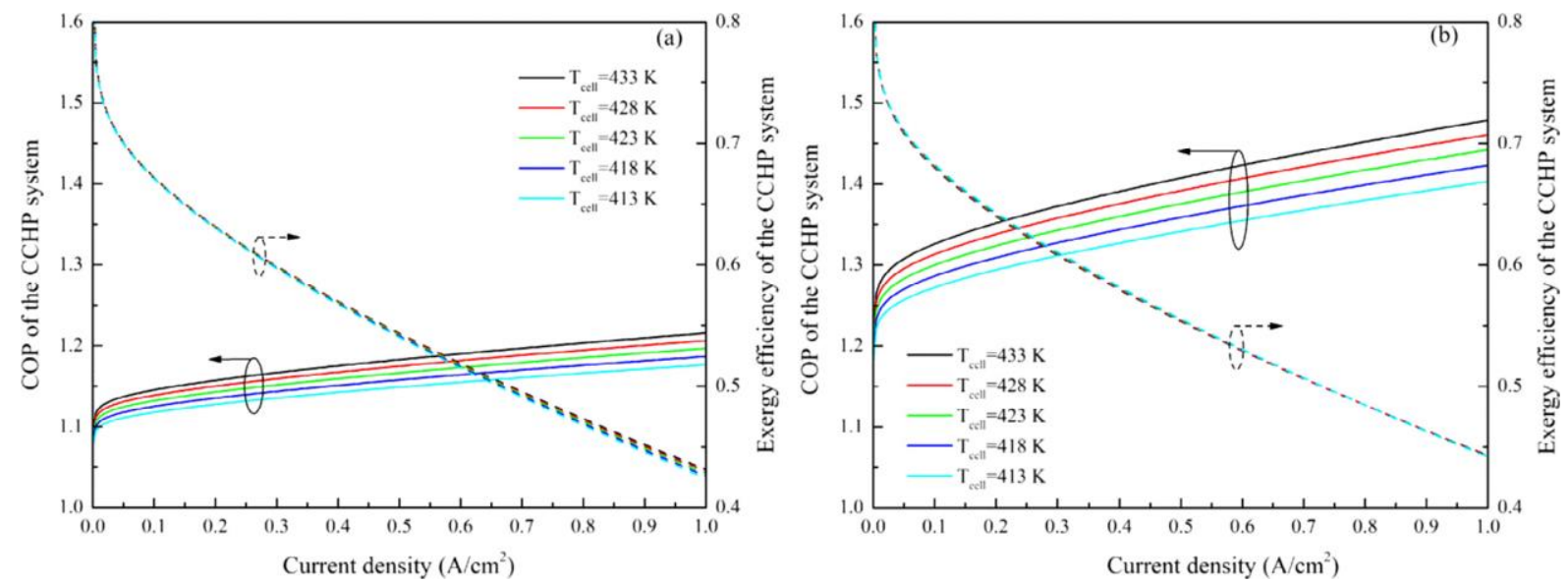

Figure 11 COP and exergy efficiency variation with current density and operating temperature (a: In summer; b: In winter).

\subsection{Effects of ambient temperature on the performance of the CCHP system}

The ambient temperature mainly affects the performance of the VCC subsystem which in turn affects the whole CCHP system. Fig. 12 shows the effects of ambient temperature on the COP and the exergy efficiency of the CCHP system. The ambient temperature changes from $301 \mathrm{~K}$ to $309 \mathrm{~K}$ in summer and from $279 \mathrm{~K}$ to $287 \mathrm{~K}$ in winter. As can be seen, the exergy efficiency is negatively 
correlated with ambient temperature both in summer and in winter, which can be explained with Eq. (26). While the COP in summer has a negative correlation with ambient temperature, and that in winter, a positive one. In addition, the COP in winter is more sensitive to the change of ambient temperature compared with that in summer, as seen in the comparison of Fig.12(a) and (b).
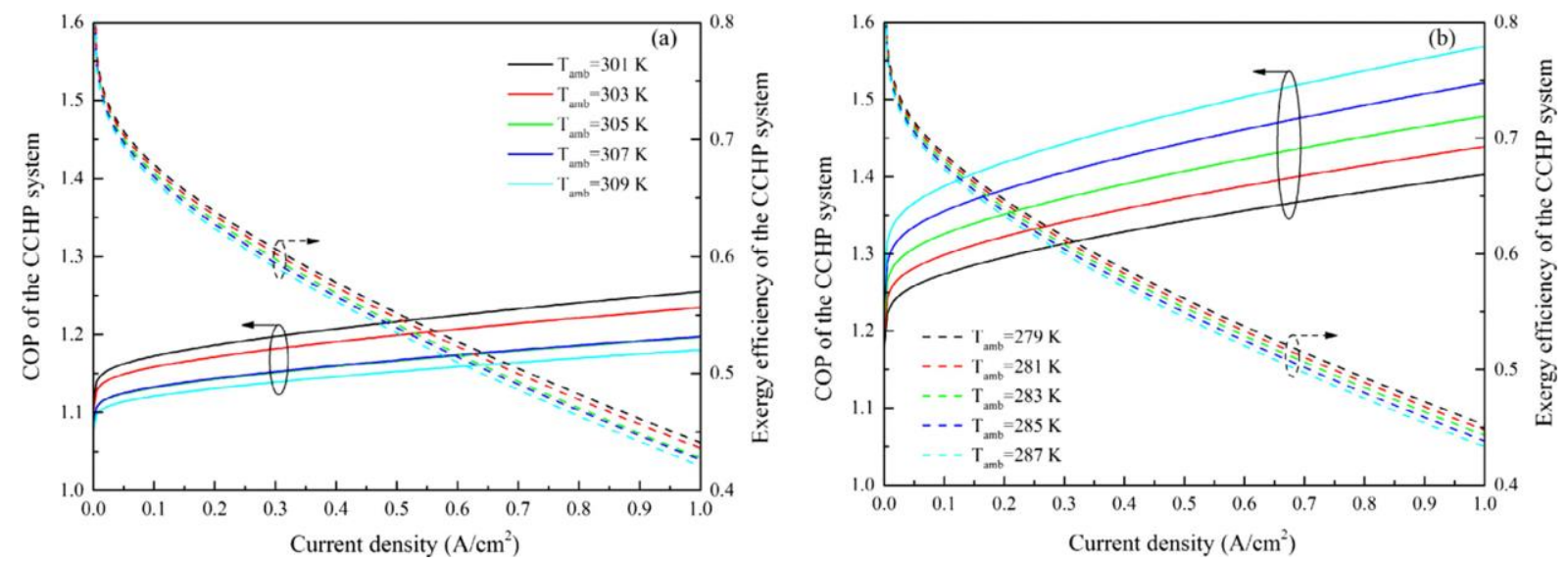

Figure 12 COP and exergy efficiency variation with ambient temperature (a: In summer; b: In winter).

\section{Conclusions}

In this study, a novel micro-CCHP system based on high-temperature PEMFC is proposed. This microCCHP system consists of a PEMFC subsystem, an ORC subsystem, and a VCC subsystem. The electric power of the CCHP system is $8 \mathrm{~kW}$, the cooling capacity is $12.5 \mathrm{~kW}$ in summer, the heating capacity is $20 \mathrm{~kW}$ in winter, and the domestic hot water power is approximately $18 \mathrm{~kW}$ under normal operating conditions. The following main conclusions are obtained:

(1) A complete model of the CCHP system including high-temperature PEMFC model, ORC model, VCC model, balance-of-plant model and the CCHP performance model is developed in Matlab coupled with REFPROP.

(2) Six different organic working fluids are investigated for utilization in the ORC subsystem. The working fluid selection is based on evaporation pressure, net output power per unit mass, the output mechanical power of the turbine expander, the COP and the exergy efficiency of the CCHP system. With consideration of the cycle performance and the physical, safety and environmental properties, R601 was eventually chosen for this system.

(3) Both the current density and the operating temperature have significant effects on the COP of the CCHP system while only the current density primarily affects the exergy performance. The ambient temperature can affect both the energy performance and the exergy performance of the CCHP system by means of affecting the performance of the VCC subsystem. The COP in winter is more sensitive to the change of ambient temperature compared with that in summer

(4) The average COP of the CCHP system is 1.19 in summer and 1.42 in winter, and the average exergy efficiency is $46 \%$ in summer and $47 \%$ in winter under normal operating conditions. 


\section{Acknowledgments}

This work is supported by the National Natural Science Foundation of China (Nos. 51376058, 51476119 and 51676067) and the International Science and Technology Cooperation Program of China (No. 2014DFA60990).

\section{References}

[1] Cho H, Smith AD, Mago P. Combined cooling, heating and power: a review of performance improvement and optimization. Appl Energy 2014;136:168-85.

[2] Li Y, Hu R. Exergy-analysis based comparative study of absorption refrigeration and electric compression refrigeration in CCHP systems. Appl Therm Eng 2016;93:1228-37.

[3] Staffell I. Zero carbon infinite COP heat from fuel cell CHP. Appl Energy 2015;147:373-85.

[4] Chen X, Gong G, Wan Z, Luo L, Wan J. Performance analysis of 5 kW PEMFC based residential micro-CCHP with absorption chiller. Int J Hydrogen Energy 2015;40:10647-57.

[5] Eyerer S, Wieland C, Vandersickel A, Spliethoff H. Experimental study of an ORC (Organic Rankine Cycle) and analysis of R1233zd-E as a drop-in replacement for R245fa for low temperature heat utilization. Energy 2016;103:660-71.

[6] Long R, Bao Y, Huang X, Liu W. Exergy analysis and working fluid selection of organic Rankine cycle for low grade waste heat recovery. Energy 2014;73:475-83.

[7] Sprouse lii C, Depcik C. Review of organic Rankine cycles for internal combustion engine exhaust waste heat recovery. Appl Therm Eng 2013;51:711-22.

[8] He S, Chang H, Zhang X, Shu S, Duan C. Working fluid selection for an organic Rankine cycle utilizing high and low temperature energy of an LNG engine. Appl Therm Eng 2015;90:579-89.

[9] Bu X, Li H, Wang L. Performance analysis and working fluids selection of solar powered organic Rankine-vapor compression ice maker. Solar Energy 2013;95:271-8.

[10] Soheyli S, Shafiei Mayam MH, Mehrjoo M. Modeling a novel CCHP system including solar and wind renewable energy resources and sizing by a CCMOPSO algorithm. Appl Energy 2016;184:37595.

[11] Maraver D, Sin A, Royo J, Sebastián F. Assessment of CCHP systems based on biomass combustion for small-scale applications through a review of the technology and analysis of energy efficiency parameters. Appl Energy 2013;102:1303-13.

[12] Mohammadi A, Ahmadi MH, Bidi M, Joda F, Valero A, Uson S. Exergy analysis of a combined cooling, heating and power system integrated with wind turbine and compressed air energy storage system. Energy Convers Manage 2017;131:69-78. 
[13] Verhaert I, Mulder G, De Paepe M. Evaluation of an alkaline fuel cell system as a micro-CHP. Energy Convers Manag 2016;126:434-45.

[14] Mortazaei M, Rahimi M. A comparison between two methods of generating power, heat and refrigeration via biomass based solid oxide fuel cell: a thermodynamic and environmental analysis. Energy Convers Manage 2016;126:132-41.

[15] Korsgaard AR, Nielsen MP, Kær SK. Part one: a novel model of HTPEM-based micro-combined heat and power fuel cell system. Int J Hydrogen Energy 2008;33:1909-20.

[16] Haghighat Mamaghani A, Najafi B, Casalegno A, Rinaldi F. Predictive modelling and adaptive long-term performance optimization of an HT-PEM fuel cell based micro combined heat and power (CHP) plant. Appl Energy 2017;192:519-29.

[17] Najafi B, Haghighat Mamaghani A, Rinaldi F, Casalegno A. Long-term performance analysis of an HT-PEM fuel cell based micro-CHP system: operational strategies. Appl Energy 2015;147:582-92.

[18] Barelli L, Bidini G, Gallorini F, Ottaviano A. Dynamic analysis of PEMFC-based CHP systems for domestic application. Appl Energy 2012;91:13-28.

[19] Oh S-D, Kim K-Y, Oh S-B, Kwak H-Y. Optimal operation of a 1-kW PEMFC based CHP system for residential applications. Appl Energy 2012;95:93-101.

[20] Adam A, Fraga ES, Brett DJ. Options for residential building services design using fuel cell based micro-CHP and the potential for heat integration. Appl Energy 2015;138:685-94.

[21] Di Marcoberardino G, Roses L, Manzolini G. Technical assessment of a micro cogeneration system based on polymer electrolyte membrane fuel cell and fluidized bed auto thermal reformer. Appl Energy 2016;162:231-44.

[22] Xie D, Wang Z, Jin L, Zhang Y. Energy and exergy analysis of a fuel cell based micro combined heat and power cogeneration system. Energy Build 2012;50:266-72.

[23] Arsalis A, Kær SK, Nielsen MP. Modeling and optimization of a heat-pump assisted high temperature proton exchange membrane fuel cell micro combined-heat-and-power system for residential applications. Appl Energy 2015;147:569-81.

[24] Facci AL, Cigolotti V, Jannelli E, Ubertini S. Technical and economic assessment of a SOFC-based energy system for combined cooling, heating and power. Appl Energy 2017;192:563-74.

[25] Calise F, Ferruzzi G, Vanoli L. Transient simulation of poly generation systems based on PEM fuel cells and solar heating and cooling technologies. Energy 2012;41:18-30.

[26] Chen X, Gong G, Wan Z, Zhang C, Tu Z. Performance study of a dual power source residential CCHP system based on PEMFC and PTSC. Energy Convers Manage 2016;119:163-76.

[27] Chang H, Wan Z, Zheng Y, Chen X, Shu S, Tu Z, et al. Energy analysis of a hybrid PEMFC-solar energy residential micro-CCHP system combined with an organic Rankine cycle and vapor compression cycle. Energy Convers Manage 2017;142:374-84. 
[28] Da Lio L, Manente G, Lazzaretto A. Predicting the optimum design of single stage axial expanders in ORC systems: is there a single efficiency map for different working fluids? Appl Energy 2016;167:44-58.

[29] Wang J, Yan Z, Wang M, Ma S, Dai Y. Thermodynamic analysis and optimization of an (organic Rankine cycle) ORC using low grade heat source. Energy 2013;49:356-65.

[30] Shu G, Liu L, Tian H, Wei H, Yu G. Parametric and working fluid analysis of a dual-loop organic Rankine cycle (DORC) used in engine waste heat recovery. Appl Energy 2014;113:1188-98.

[31] Cataldo F, Mastrullo R, Mauro AW, Vanoli GP. Fluid selection of organic Rankine cycle for lowtemperature waste heat recovery based on thermal optimization. Energy 2014;72:159-67.

[32] Najafi B, Obando Vega P, Guilizzoni M, Rinaldi F, Arosio S. Fluid selection and parametric analysis on condensation temperature and plant height for a thermogravimetric heat pump. Appl Therm Eng 2015;78:51-61.

[33] Heberle F, Brüggemann D. Exergy based fluid selection for a geothermal organic Rankine cycle for combined heat and power generation. Appl Therm Eng 2010;30:1326-32.

[34] Liu Q, Shen A, Duan Y. Parametric optimization and performance analyses of geothermal organic Rankine cycles using R600a/R601a mixtures as working fluids. Appl Energy 2015;148:410-20.

[35] Nasir MT, Kim KC. Working fluids selection and parametric optimization of an organic Rankine cycle coupled Vapor Compression Cycle (ORC-VCC) for air conditioning using low grade heat. Energy Build 2016;129:378-95.

[36] Qiu G. Selection of working fluids for micro-CHP systems with ORC. Renew Energy 2012;48:56570.

[37] Tuo H. Energy and exergy-based working fluid selection for organic Rankine cycle recovering waste heat from high temperature solid oxide fuel cell and gas turbine hybrid systems. Int J Energy Res 2013;37:1831-41.

[38] Al-Sulaiman FA, Dincer I, Hamdullahpur F. Exergy analysis of an integrated solid oxide fuel cell and organic Rankine cycle for cooling, heating and power production. J Power Sour 2010;195:234654.

[39] Aminyavari M, Mamaghani AH, Shirazi A, Najafi B, Rinaldi F. Exergetic, economic, and environmental evaluations and multi-objective optimization of an internal-reforming SOFC-gas turbine cycle coupled with a Rankine cycle. Appl Therm Eng 2016;108:833-46.

[40] Ebrahimi M, Moradpoor I. Combined solid oxide fuel cell, micro-gas turbine and organic Rankine cycle for power generation (SOFC-MGT-ORC). Energy Convers Manage 2016;116:120-33.

[41] Arsalis A, Nielsen MP, Kær SK. Modeling and off-design performance of a 1 kWe HT-PEMFC (high temperature-proton exchange membrane fuel cell)-based residential micro-CHP (combined-heatand-power) system for Danish single family households. Energy 2011;36:993-1002. 
[42] Korsgaard AR, Refshauge R, Nielsen MP, Bang M, Kær SK. Experimental characterization and modeling of commercial polybenzimidazole-based MEA performance. J Power Sour 2006;162:23945. 